\title{
Stability indicating simultaneous validation of Paracetamol, Phenylpropanolamine and Triprolidine with forced degradation behavior study by RP-HPLC in pharmaceutical dosage form
}

\author{
Anurag Mishra ${ }^{1}$, Akhilesh Sharma ${ }^{1}$, Sanjay Sharma ${ }^{2}$ \\ ${ }^{1}$ Research Scholar, Pacific Academy of Higher Education and Research University, Udaipur, India \\ ${ }^{2}$ Associate Professor, School of Pharmacy and Technology Management, SVKM's NMIMS, Shirpur, India
}

Received: 20-05-2018 / Revised: 15-06-2018 / Accepted: 22-07-2018

\begin{abstract}
A simple, precise, and accurate RP-HPLC method has been developed and validated for the simultaneous assay of Paracetamol, Phenylpropanolamine and Triprolidinein tablet dosage form. Isocratic RP-HPLC method was developed on BDS hypersil C18, $(250 \mathrm{~mm} \times 4.6 \mathrm{~mm}$ internal diameter, $5 \mu$ particle size $)$ using mobile phase as Water $(\mathrm{pH}-4.0)$ : Methanol $(70: 30 \mathrm{v} / \mathrm{v})$ at a flow rate of $1.0 \mathrm{~mL} / \mathrm{min}$ and the detection was carried out at $220 \mathrm{~nm}$ using tunable absorbance detector (Waters 486). Forced degradation study was carried out by acid degradation, base degradation, thermal degradation, oxidation of the drug. The method was validated for linearity, precision, accuracy and robustness. It was found to ideally resolve the peaks with retention time (RT) 4.053min,5.603min and 11.083 min for Phenylpropanolamine, Paracetamol and Triprolidine respectively.The method was found to be linear in the concentration range of $50-150 \mu \mathrm{g} / \mathrm{mL}$ with correlation coefficient of 0.9994 for Paracetamol, $2.5-7.5 \mu \mathrm{g} / \mathrm{mL}$ with correlation coefficient of 0.9995 for Phenylpropanolamineand $2.5-7.5 \mu \mathrm{g} / \mathrm{mL}$ with correlation coefficient of 0.9992 for Triprolidine. Degradation products produced as a result of stress studies did not interfere with the detection of Paracetamol, Phenylpropanolamine and Triprolidine; therefore, the assay can be considered to be stability indicating.
\end{abstract}

Keywords: HPLC, Paracetamol, Phenylpropanolamine, Triprolidine, Validation, Forced degradation.

\begin{abstract}
Introduction
Paracetamol's empirical formula is $\mathrm{C}_{8} \mathrm{H}_{9} \mathrm{NO}_{2}$ and its IUPAC name is $N$-(4-hydroxyphenyl) ethanamide $N$ (4hydroxyphenyl) acetamide. Figure 1 shows chemical structure of Paracetamol. Paracetamol is organic compound containing an acetamide group conjugated to a phenyl group of Benzenoids group. Paracetamol is thought to act primarily in the CNS, increasing the pain threshold by inhibiting both isoforms of cyclooxygenase, COX-1, COX-2, and COX-3 enzymes involved in prostaglandin (PG) synthesis. Phenylpropanolamine's empirical formula is $\mathrm{C}_{9} \mathrm{H}_{14} \mathrm{NCl}$ and its IUPAC name is (1S,2R)-2-amino-1phenylpropan-1-ol.
\end{abstract}

*Correspondence

Anurag Mishra

Research Scholar, Pacific Academy of Higher

Education and Research University, Udaipur, India

E-Mail: raag.mishra@gmail.com
Figure 2 shows chemical structure of Phenylpropanolamine. Phenylpropanolamine is a drug with adrenergic agonist properties. Phenylpropanolamine acts directly on alpha- and, to a lesser degree, beta-adrenergic receptors in the mucosa of the respiratory tract. Stimulation of alpha-adrenergic receptors produces vasoconstriction, reduces tissue hyperemia, edema, and nasal congestion, and increases nasal airway patency. It indirectly stimulates betareceptors, producing tachycardia and a positive inotropic effect. Triprolidine's empirical formula is $\mathrm{C}_{19} \mathrm{H}_{22} \mathrm{~N}_{2}$ and its IUPAC name is 2-[(E)-1-(4methylphenyl)-3-pyrrolidin-1-yl-prop-1-enyl]

pyridine.Figure 3 shows the chemical structure of Triprolidine.Triprolidine is first generation histamine H1 antagonist used in allergic rhinitis; asthma; and urticaria. It is a component of cough and cold medicines and may cause drowsiness Triprolidine binds to the histamine $\mathrm{H} 1$ receptor. This blocks the action of endogenous histamine, which subsequently 
leads to temporary relief of the negative symptoms brought on by histamine.

Literature survey reveals that quantitative analysis of Paracetamol, Phenylpropanolamine and Triprolidine have been done separately or in combination of two and in combination of other drugs but no method is reported for the simultaneous estimation of
Paracetamol, Phenylpropanolamine and Triprolidinein combined dosage form. The present study involved the development and validation of RP-HPLC method for the estimation of Paracetamol, Phenylpropanolamine and Triprolidinein combined pharmaceutical dosage form (tablet) and their forced degradation study(1-3).

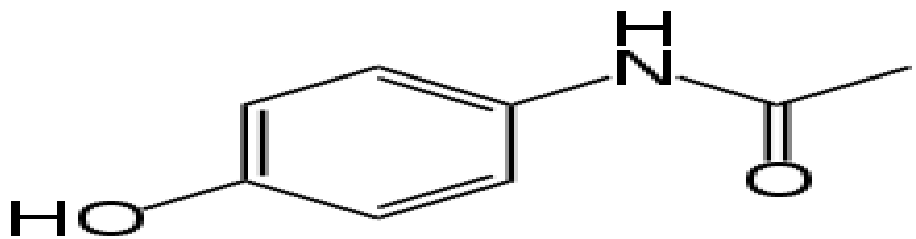

Fig 1: Structure of Paracetamol

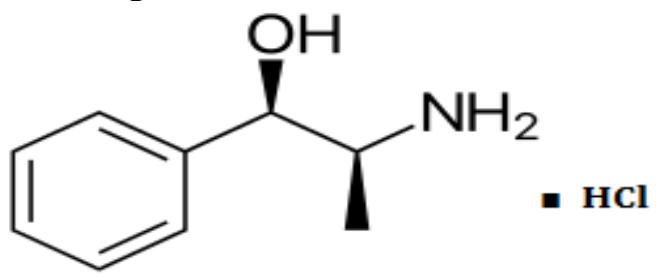

Fig 2: Structure of Phenylpropanolamine

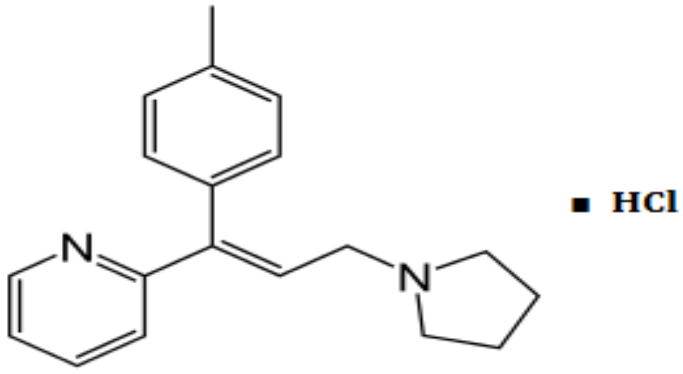

Fig 3: Structure of Triprolidine

\section{Material and Methods \\ Instruments}

The liquid chromatographic system consists of Waters series M510 equipped with a tunable absorbance detector (Waters 486), HPLC pump (Waters 510), and manual injector rheodyne valve with $20 \mu \mathrm{L}$ fixed loop. The analytes were monitored at $220 \mathrm{~nm}$. Chromatographic analysis was performed on Thermo scientific BDS hypersil C18, $(250 \mathrm{~mm} \times 4.6 \mathrm{~mm}$ internal diameter, $5 \mu$ particle size). All the drugs and chemicals were weighed on Citizen electronic balance. Chemiline India $\mathrm{pH}$ meter and Toshcon Ultrasonicator was used.

\section{Chemicals and reagents}

Methanolwas of HPLC grade obtained from Merck Ltd., Mumbai. Water was of HPLC grade prepared by triple distillation method. Sodium Hydroxide $(\mathrm{NaOH})$,
Hydrogen Peroxide $\left(\mathrm{H}_{2} \mathrm{O}_{2}\right)$ and Hydrochloric Acid $(\mathrm{HCl})$ were of $\mathrm{AR}$ grade and were obtained from Merck, Mumbai India. Paracetamol reference standard, Phenylpropanolamine and Triprolidine reference standards were procured from Yash Pharma. Actifed Plus containing $100 \mathrm{mg}$ of Paracetamol, 5mg of Phenylpropanolamine and $0.5 \mathrm{mg}$ of Triprolidine manufactured by Glaxo SmithKline Pharmaceuticals Ltdwas procured from local market.

\section{HPLC Conditions}

The mobile phase consisted of Water ( $\mathrm{pH}-4.0)$ : Methanol (70:30v/v). The mobile phase was prepared freshly and it was sonicated by using ToshconUltrasonicator for $5 \mathrm{~min}$ before use. BDS hypersil C18, $(250 \mathrm{~mm} \times 4.6 \mathrm{~mm}$ internal diameter, $5 \mu$ particle size) was used and it was equilibrated for at least $30 \mathrm{~min}$ with the mobile phase flowing through the 
system. The column and the HPLC system were kept at ambient temperature. The eluent was monitored by UV detection at $220 \mathrm{~nm}$. Analysis was done at flowrate of $1.0 \mathrm{ml} / \mathrm{min}$ with $20 \mu \mathrm{l}$ volume of injection. All data were analyzed by using Empower 3 software.

\section{Preparation of Mobile Phase}

The mobile phase was prepared by mixing Water ( $\mathrm{pH}-$ 4.0) and Methanol in the ratio of $(70: 30 \% \mathrm{v} / \mathrm{v})$. The solution was then filtered through 0.45 microns membrane filter and degassed.

\section{Preparation of standard stock solution}

Standard stock solution of Paracetamol, Phenylpropanolamine and Triprolidinewere prepared by accurately weighing $100 \mathrm{mg}, 50 \mathrm{mg}$ and $50 \mathrm{mg}$ respectively and dissolving them separately in $100 \mathrm{ml}$ with methanol to prepare solution of $1000 \mu \mathrm{g} / \mathrm{ml}$, $50 \mu \mathrm{g} / \mathrm{ml}$ and $50 \mu \mathrm{g} / \mathrm{ml}$.

\section{Preparation of working standard solution}

Add $1 \mathrm{ml}$ each of standard stock solution of Paracetamol, Phenylpropanolamine and Triprolidinein $10 \mathrm{ml}$ volumetric flask and volume make up to $10 \mathrm{ml}$ with methanol.

\section{Preparation of sample stock solution}

Weigh tablet powder equivalent to $5 \mathrm{mg}$ of Phenylpropanolamine, $100 \mathrm{mg}$ of Paracetamol and $0.5 \mathrm{mg}$ of Triprolidine) into a $100 \mathrm{ml}$ volumetric flask. Add $60 \mathrm{ml}$ methanol andshake for 15 minutes. Make up volume with methanol upto $100 \mathrm{ml}$. Filter this solution.

\section{Preparation of sample working solution}

Take $1 \mathrm{ml}$ from sample stock solution into a $10 \mathrm{ml}$ volumetric flask, add $1 \mathrm{ml}$ Triprolidine standard stock solution and make up with mobile phase to prepare a solution of Phenylpropanolamine $5 \mathrm{mcg} / \mathrm{ml}$, Paracetamol $100 \mathrm{mcg} / \mathrm{ml}$ and Triprolidine $5.5 \mathrm{mcg} / \mathrm{ml}$ (Triprolidine $0.5 \mathrm{mcg}+$ Triprolidine standard $5 \mathrm{mcg}$ ).

\section{Forced Degradation Study}

\section{Preparation of solution for acid degradation}

Acid decomposition study was performed by keeping the working solution of all three drugs $(1 \mathrm{ml})$ in $2 \mathrm{ml}$ of $0.1 \mathrm{~N} \mathrm{HCl}$ for $4 \mathrm{hrs}$. After $4 \mathrm{hrs}$ solution neutralized with $2 \mathrm{ml} 0.1 \mathrm{~N} \mathrm{NaOH}$ and finally made up to $10 \mathrm{ml}$ volume with mobile phase, sonicated and filtered through $0.45 \mu \mathrm{m}$ membrane filter paper and injected in to HPLC system. Degradation samples were prepared as blank sample, separate standard samples and combined sample of all three drugs.
Preparation of solution for basic degradation Alkali decomposition study was performed by keeping the working solution of all three drugs $(1 \mathrm{ml})$ in $2 \mathrm{ml}$ of $0.1 \mathrm{~N} \mathrm{NaOH}$ for $4 \mathrm{hrs}$. After 4 hrs solution neutralized with $2 \mathrm{ml}$ of $0.1 \mathrm{~N} \mathrm{HCL}$ and finally made up to $10 \mathrm{ml}$ volume with mobile phase, sonicated and filtered through $0.45 \mu \mathrm{m}$ membrane filter paper and injected in to HPLC system. Degradation samples were prepared as blank sample, separate standard samples and combined sample of all three drugs.

\section{Preparation of solution for oxidative degradation} Oxidative decomposition study was performed by keeping the working solution of all three drugs $(1 \mathrm{ml})$ in $2 \mathrm{ml} 3 \% \mathrm{H}_{2} \mathrm{O}_{2}$ for $5 \mathrm{hrs}$. After $5 \mathrm{hrs}$ volume made up to $10 \mathrm{ml}$ with mobile phase,sonicated and filtered through $0.45 \mu \mathrm{m}$ membrane filter paper and injected into HPLC system. Degradation samples were prepared as blank sample, separate standard samples and combined sample of all three drugs.

\section{Preparation of solution for thermal degradation}

Thermal decomposition study was performed by refluxing the working solution of all three drugs $(1 \mathrm{ml})$ for $24 \mathrm{hrs}$ at $105^{\circ} \mathrm{C}$. After $24 \mathrm{hrs}$ volume made up to 10 $\mathrm{ml}$ volume with mobile phase, sonicated and filtered through $0.45 \mu \mathrm{m}$ membrane filter paper and injected into HPLC system. Degradation samples were prepared as blank sample, separate standard samples and combined sample of all three drugs.

\section{Preparation of solution for UV degradation}

UV degradation was performed by exposing the working solution of all three drugs $(1 \mathrm{ml})$ to Sunlight for 24 hours. After 24 hours volume made up to $10 \mathrm{ml}$ volume with mobile phase, sonicated and filtered through $0.45 \mu \mathrm{m}$ membrane filter paper and injected into HPLC system. Degradation samples were prepared as blank sample, separate standard samples and combined sample of all three drugs were prepared.

\section{Determination of $\lambda$ max}

The UV spectra of standard stock solutions of Paracetamol, Phenylpropanolamine and Triprolidine were taken between the wave length range of 200$400 \mathrm{~nm}$ using methanol as blank. The $\lambda$ max was found to be $245.93 \mathrm{~nm}, 232.95 \mathrm{~nm}$ and $183.31 \mathrm{~nm}$ for Paracetamol, Phenylpropanolamine and Triprolidine respectively. Overlay of the three spectra taken and isoabsorptive point was selected and it was found that all three drugs show appreciable absorbance at $220 \mathrm{~nm}$, so it is used for the further study. 


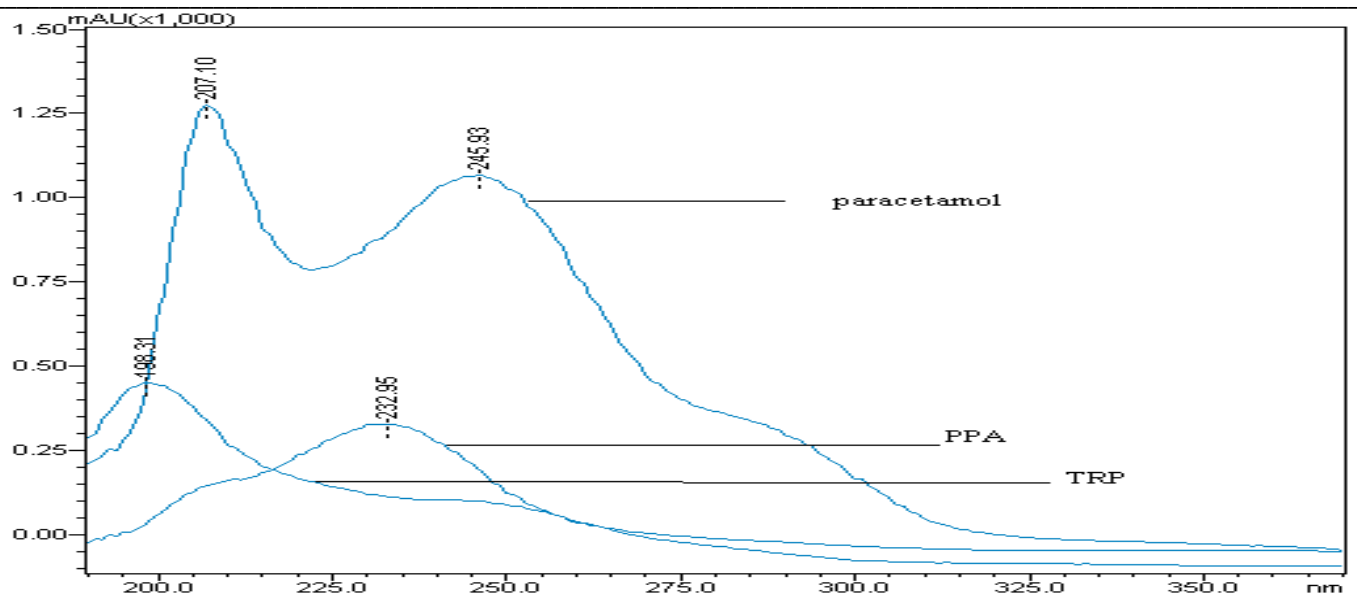

Fig 4: Overlay absorption spectrum for Paracetamol, Phenylpropanolamine and Triprolidine

\section{Procedure of Analysis}

$1 \mathrm{ml}$ from Paracetamol Standard stock solution, $1 \mathrm{ml}$ from Phenylpropanolamine Standard stock solution and $1 \mathrm{ml}$ from Triprolidine Standard stock solution were taken and volume was make up to $10 \mathrm{ml}$ with Mobile phase to obtain Working standard solution containing Paracetamol $\quad(100 \mu \mathrm{g} / \mathrm{mL})$, Phenylpropanolamine $(5 \mu \mathrm{g} / \mathrm{mL})$ and Triprolidine $(5 \mu \mathrm{g} / \mathrm{mL})$. The contents of standard and sample solution were then filtered through
$0.45 \mu \mathrm{m}$ syringe filter. Chromatograms standard solution (six replicates) was recorded. A typical chromatogram of Paracetamol, Phenylpropanolamine and Triprolidineis presented in figure 5. The retention time of Paracetamol, Phenylpropanolamine and Triprolidinewere $5.603 \mathrm{~min}, 4.653 \mathrm{~min}$ and $11.083 \mathrm{~min}$ respectively. The peak areas were measured and the quantitation was carried out by keeping these values to the regression equation of calibration curve.

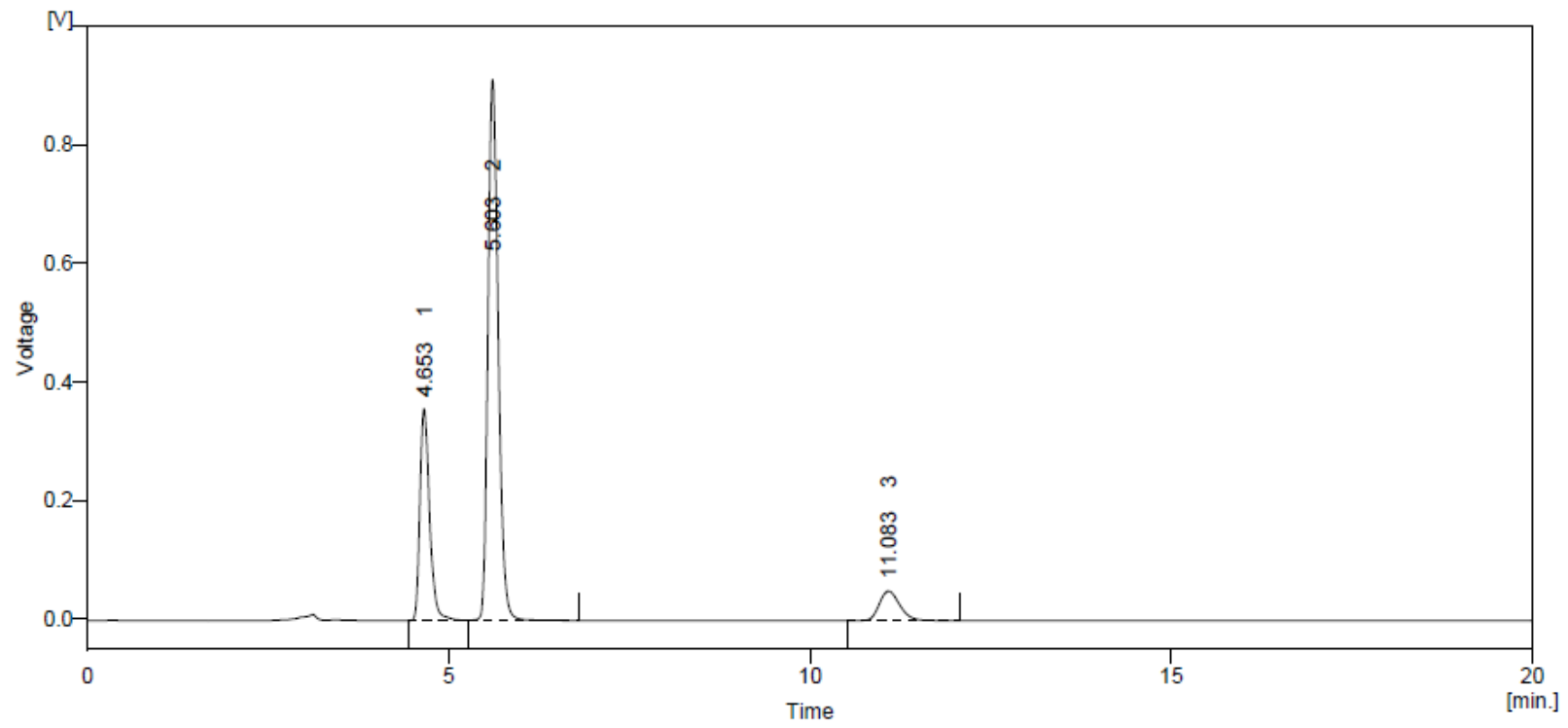

Fig 5: Standard Chromatograms of Paracetamol, Phenylpropanolamine and Triprolidine

Optimized Chromatographic Condition

Stationary phase: Thermo scientific BDS hypersil $\mathrm{C}_{18}(250 \mathrm{~mm} \times 4.6 \mathrm{~mm}, 5 \mu)$.

Mobile phase

Flow rate

: Water (pH 4.0): Methanol (70:30 v/v)

Run time (min) $: 15 \mathrm{~min}$

Detection : At $220 \mathrm{~nm}$

Injection (volume) $\quad: 20 \mu 1$ 
Table 1: System suitability of proposed method

\begin{tabular}{|l|c|c|c|}
\hline Parameters & Paracetamol & Phenylpropanolamine & Triprolidine \\
\hline Theoretical plates & 7398 & 5839 & 7396 \\
\hline Resolution & - & 3.769 & 14.122 \\
\hline Asymmetry & 1.398 & 1.563 & 1.366 \\
\hline Retention time & $5.603 \mathrm{~min}$ & $4.653 \mathrm{~min}$ & $11.083 \mathrm{~min}$ \\
\hline
\end{tabular}

\section{Method validation procedure}

The developed method was validated for the parameters listed in ICH guidelines (4-7).

\section{Linearity}

The method was linear in the range of $50-150 \mu \mathrm{g} / \mathrm{mL}$, 2.5-7.5 $\mu \mathrm{g} / \mathrm{mL}$ and $2.5-7.5 \mu \mathrm{g} / \mathrm{mL}$ for Paracetamol, Phenylpropanolamine and Triprolidine respectively.
The linear correlation coefficient for Paracetamol, Phenylpropanolamine and Triprolidine were found to be $0.9994,0.9995$ and 0.9992 respectively, and are recorded in table 2, 3 and 4. Calibration curve of Paracetamol, Phenylpropanolamine and Triprolidinewas obtained by plotting the peak area ratio versus the respective concentrations (Figure 6, 7 and $8)$.

Table 2: Linearity results of Paracetamol

\begin{tabular}{|l|l|l|}
\hline Linearity Level & Concentration & Area \\
\hline I & $50 \mu \mathrm{g} / \mathrm{ml}$ & 4633.059 \\
\hline II & $75 \mu \mathrm{g} / \mathrm{ml}$ & 7003.539 \\
\hline III & $100 \mu \mathrm{g} / \mathrm{ml}$ & 9079.044 \\
\hline IV & $125 \mu \mathrm{g} / \mathrm{ml}$ & 11424.241 \\
\hline V & $150 \mu \mathrm{g} / \mathrm{ml}$ & 13463.017 \\
\hline Correlation coefficient & 0.9994 \\
\hline
\end{tabular}

Table 3: Linearity of Phenylpropanolamine

\begin{tabular}{|l|l|l|}
\hline Linearity Level & Concentration & Area \\
\hline I & $2.5 \mu \mathrm{g} / \mathrm{ml}$ & 1706.569 \\
\hline II & $3.75 \mu \mathrm{g} / \mathrm{ml}$ & 2581.360 \\
\hline III & $5 \mu \mathrm{g} / \mathrm{ml}$ & 3336.578 \\
\hline IV & $6.25 \mu \mathrm{g} / \mathrm{ml}$ & 4209.745 \\
\hline V & $7.5 \mu \mathrm{g} / \mathrm{ml}$ & 4981.000 \\
\hline Correlation coefficient & 0.9995 \\
\hline
\end{tabular}

Table 4: Linearity of Triprolidine

\begin{tabular}{|l|l|l|}
\hline Linearity Level & Concentration & Area \\
\hline I & $2.5 \mu \mathrm{g} / \mathrm{ml}$ & 495.645 \\
\hline II & $3.75 \mu \mathrm{g} / \mathrm{ml}$ & 742.735 \\
\hline III & $5 \mu \mathrm{g} / \mathrm{ml}$ & 977.866 \\
\hline IV & $6.25 \mu \mathrm{g} / \mathrm{ml}$ & 1220.885 \\
\hline V & $7.5 \mu \mathrm{g} / \mathrm{ml}$ & 1430.128 \\
\hline Correlation coefficient & 0.9992 \\
\hline
\end{tabular}




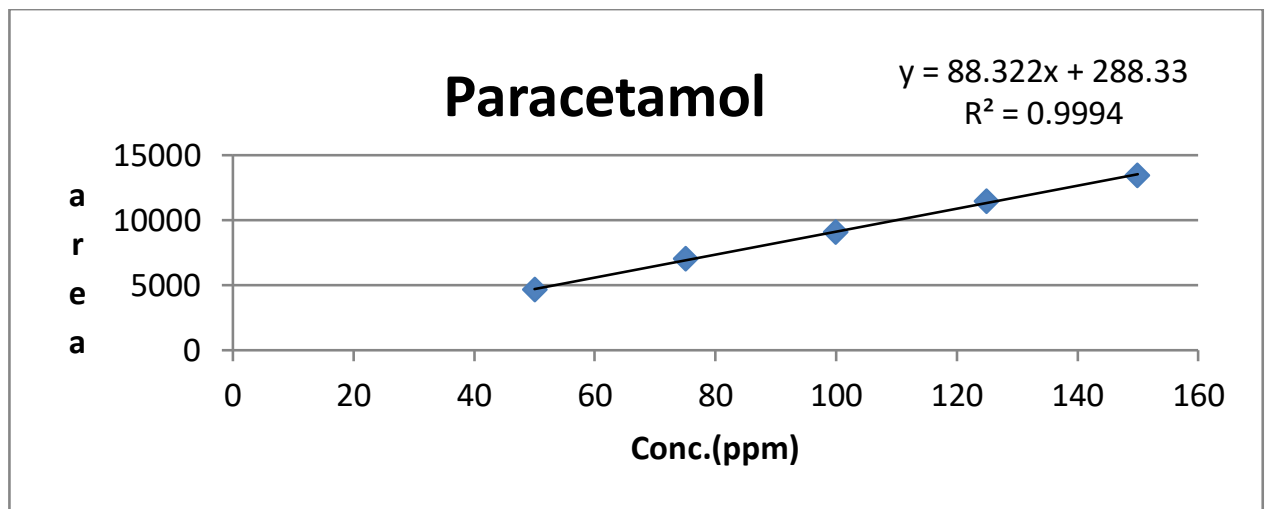

Fig 6: Calibration curve of Paracetamol

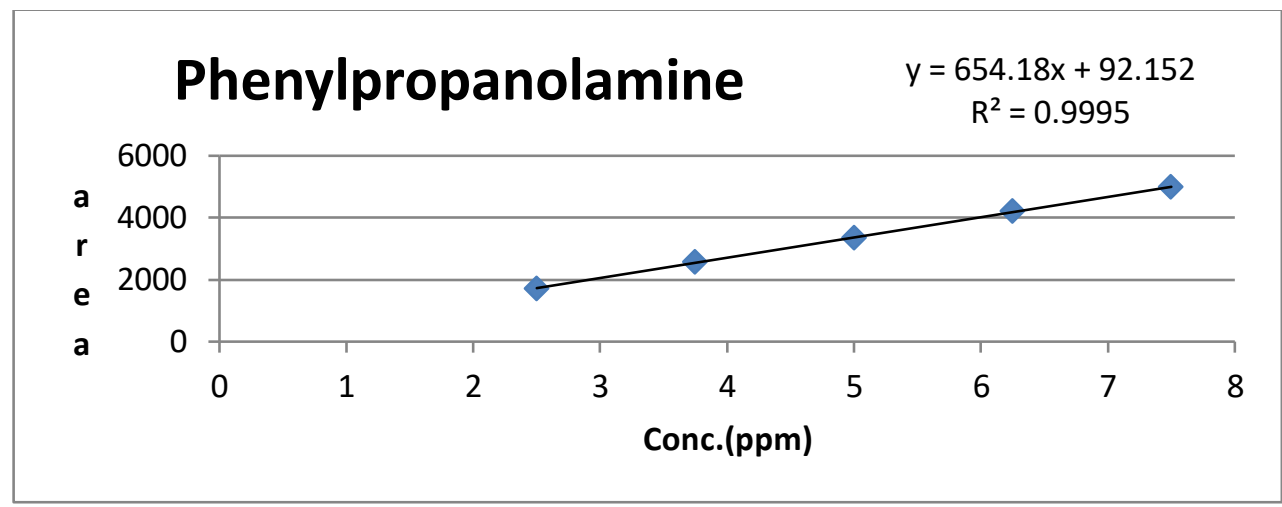

Fig 7: Calibration curve of Phenylpropanolamine

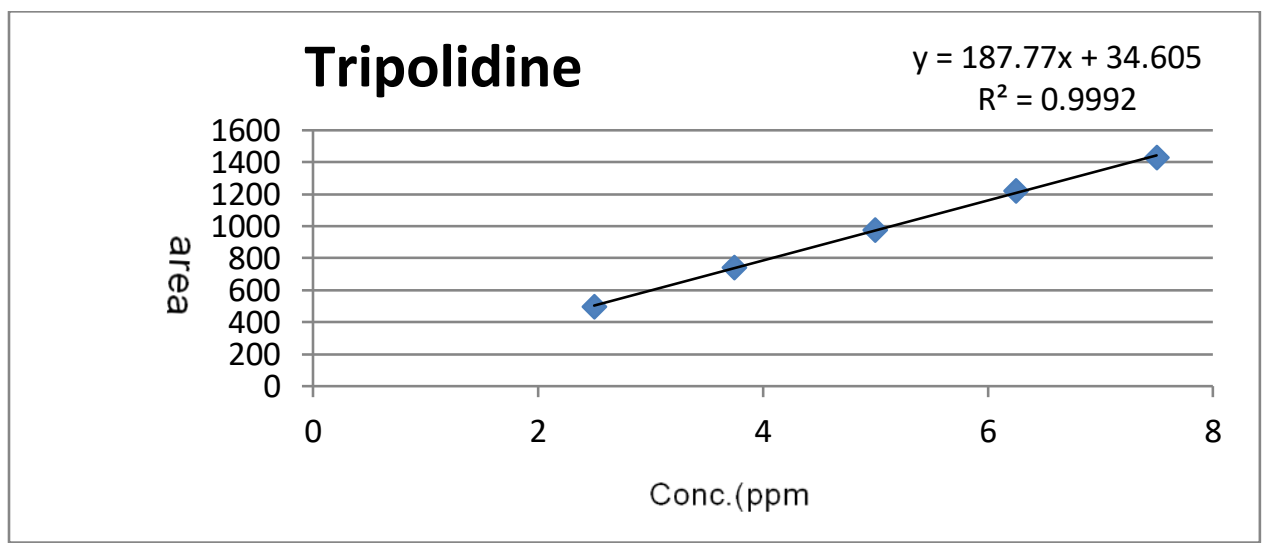

Fig 8: Calibration curve of Triprolidine

\section{Accuracy}

The accuracy of the method was determined by recovery experiment and known concentration of working standard was added to the fixed concentration of the pre-analyzed tablet solution. Percent recovery was calculated by comparing the area before and after the addition of working standard and recovery was performed in the same way for all the three drugs. The recovery studies were performed in triplicate and results are recorded in table 5. This standard addition method was performed at $80 \%, 100 \%, 120 \%$ level and the percentage recovery was calculated. Percent recovery was within the range of 99.206-100.578 for Paracetamol, 98.923-99.943 for Phenylpropanolamine and99.727-100.308 for Triprolidinewhich indicates that the method was accurate. 
Table 5: Results of Accuracy

\begin{tabular}{|c|c|c|c|c|c|}
\hline Sample & Accuracy & $\begin{array}{l}\text { Standard } \\
\text { Drug }(\mu \mathrm{g} / \mathrm{ml})\end{array}$ & $\begin{array}{l}\text { Sample Drug } \\
(\mu \mathrm{g} / \mathrm{ml})\end{array}$ & \% of recovery & S.D. \\
\hline \multirow[t]{3}{*}{ Paracetamol } & $80 \%$ & 40 & 50 & 100.578 & 0.522 \\
\hline & $100 \%$ & 50 & 50 & 99.206 & 1.504 \\
\hline & $120 \%$ & 60 & 50 & 100.136 & 0.264 \\
\hline \multirow[t]{3}{*}{ Phenylpropanolamine } & $80 \%$ & 2 & 2.5 & 99.943 & 0.971 \\
\hline & $100 \%$ & 2.5 & 2.5 & 98.923 & 1.268 \\
\hline & $120 \%$ & 3 & 2.5 & 99.894 & 0.439 \\
\hline \multirow[t]{3}{*}{ Triprolidine } & $80 \%$ & 4 & 0.25 & 100.288 & 1.013 \\
\hline & $100 \%$ & 5 & 0.25 & 99.727 & 0.504 \\
\hline & $120 \%$ & 6 & 0.25 & 100.308 & 0.265 \\
\hline
\end{tabular}

\section{Precision}

For the precision study, repeatability study was carried out for short time interval under the same chromatographic condition. The sample was injected in six replicates and peak area for all the six replicates was recorded. The mean and \% relative standard deviation (\%RSD) was calculated and the results are shown in table 6. The \%RSD for Paracetamol,
Phenylpropanolamine and Triprolidine were found to be $0.778 \%, 0.869 \%$ and $0.924 \%$ respectively. From the data obtained the developed RP-HPLC method was found to be precise. For interday and intraday precision three different concentrations $(50 \%, 100 \%$ and $150 \%$ of analyte) of standard solutions were injected on same day and three consecutive days in three replicates and results were recorded in table $7 \& 8$.

Table 6: Results of Precision

\begin{tabular}{|l|c|c|c|}
\hline Injection & Area of Paracetamol & Area of Phenylpropanolamine & Area of Triprolidine \\
\hline Injection 1 & 9122.124 & 3359.548 & 978.816 \\
\hline Injection 2 & 9076.541 & 3335.379 & 975.895 \\
\hline Injection 3 & 9017.960 & 3321.314 & 967.660 \\
\hline Injection 4 & 9000.116 & 3309.954 & 967.635 \\
\hline Injection 5 & 8999.830 & 3302.161 & 956.177 \\
\hline Injection 6 & 8918.921 & 3275.594 & 958.962 \\
\hline Average & 9022.582 & 3317.325 & 967.524 \\
\hline S.D. & 70.156 & 28.811 & 8.941 \\
\hline \% RSD & 0.778 & 0.869 & 0.924 \\
\hline
\end{tabular}

Table 7: Result of Interday Precision

\begin{tabular}{|c|c|c|c|l|l|c|c|c|}
\hline \multicolumn{3}{|c|}{ Conc. $(\mu \mathrm{gg} / \mathrm{ml})$} & \multicolumn{3}{c|}{ Area } & \multicolumn{3}{c|}{ \% RSD } \\
\hline $\begin{array}{l}\text { Paracet } \\
\text { amol }\end{array}$ & $\begin{array}{l}\text { Phenylprop } \\
\text { anolamine } \\
\text { Triprol } \\
\text { idine }\end{array}$ & $\begin{array}{l}\text { Paracetam } \\
\text { ol }\end{array}$ & $\begin{array}{l}\text { Phenylprop } \\
\text { anolamine }\end{array}$ & $\begin{array}{l}\text { Triprolidi } \\
\text { ne }\end{array}$ & Paracetamol & $\begin{array}{l}\text { Phenyl } \\
\text { propan } \\
\text { olamine }\end{array}$ & $\begin{array}{l}\text { Tripr } \\
\text { olidin } \\
\text { e }\end{array}$ \\
\hline 50 & 2.5 & 2.5 & 4528.097 & 1662.431 & 485.395 & 0.849 & 1.321 & 0.759 \\
\hline 100 & 5 & 5 & 9008.891 & 3312.439 & 969.738 & 0.579 & 0.607 & 0.554 \\
\hline 150 & 7.5 & 7.5 & 13594.07 & 4994.392 & 1461.311 & 1.034 & 1.144 & 0.902 \\
\hline
\end{tabular}


Table 8: Result of Intraday Precision

\begin{tabular}{|c|c|c|l|l|l|l|l|l|}
\hline \multicolumn{4}{|l|}{ Conc. $(\boldsymbol{\mu g} / \mathrm{ml})$} & \multicolumn{2}{l|}{ Area } & \multicolumn{2}{l|}{ RSD } \\
\hline $\begin{array}{l}\text { Paracet } \\
\text { amol }\end{array}$ & $\begin{array}{l}\text { Phenylprop } \\
\text { anolamine }\end{array}$ & $\begin{array}{l}\text { Triproli } \\
\text { dine }\end{array}$ & $\begin{array}{l}\text { Paracetam } \\
\text { ol }\end{array}$ & $\begin{array}{l}\text { Phenylprop } \\
\text { anolamine }\end{array}$ & $\begin{array}{l}\text { Triprolidi } \\
\text { ne }\end{array}$ & $\begin{array}{l}\text { Paracet } \\
\text { amol }\end{array}$ & $\begin{array}{l}\text { Phenylprop } \\
\text { anolamine }\end{array}$ & $\begin{array}{l}\text { Tripro } \\
\text { lidine }\end{array}$ \\
\hline 50 & 2.5 & 2.5 & 4528.097 & 1662.431 & 485.395 & 0.849 & 1.321 & 0.759 \\
\hline 100 & 5 & 5 & 9008.891 & 3312.439 & 969.738 & 0.579 & 0.607 & 0.554 \\
\hline 150 & 7.5 & 7.5 & 13594.07 & 4994.392 & 1461.311 & 1.034 & 1.144 & 0.902 \\
\hline
\end{tabular}

Limit of Detection (LOD) and Limit of Quantification (LOQ)

The limit of detection and quantification were calculated using standard deviation of response and slope of the calibration curve and results are recorded table 9. The LOD for Paracetamol, Phenylpropanolamineand Triprolidine was found to be
$3.716 \mu \mathrm{g} / \mathrm{ml}, \quad 0.174 \mu \mathrm{g} / \mathrm{ml}$ and $0.210 \mu \mathrm{g} / \mathrm{ml}$ respectively. The LOQ is the smallest concentration of the analyte, which gives response that can be accurately quantified. The LOQ for Paracetamol, Phenylpropanolamine and Triprolidinewas 11.261 $\mu \mathrm{g} / \mathrm{ml}, 0.529 \mu \mathrm{g} / \mathrm{ml}$ and $0.638 \mu \mathrm{g} / \mathrm{ml}$.

Table 9: Results of LOD and LOQ

\begin{tabular}{|l|l|l|l|}
\hline Parameter & Paracetamol $(\boldsymbol{\mu g} / \mathbf{m l})$ & $\begin{array}{l}\text { Phenylpropanolamine } \\
(\boldsymbol{\mu g} / \mathbf{m l})\end{array}$ & Triprolidine $(\boldsymbol{\mu g} / \mathbf{m l})$ \\
\hline LOD & 3.716 & 0.174 & 0.210 \\
\hline LOQ & 11.261 & 0.529 & 0.638 \\
\hline
\end{tabular}

\section{Robustness}

Robustness of the method was checked by making slight deliberate changes in chromatographic conditions like flow rate, mobile phase ratio and $\mathrm{pH}$ of buffer and the result were recorded in table 10. It was observed that there were no marked changes in chromatograms and $\%$ relative standard deviation was found below 2\%, which demonstrated that the developed RP-HPLC method is robust.

Table 10: Results of Robustness

\begin{tabular}{|c|c|c|c|c|c|c|c|}
\hline \multirow{2}{*}{$\begin{array}{c}\text { Conditi } \\
\text { on }\end{array}$} & \multirow{2}{*}{$\begin{array}{c}\text { Variatio } \\
\mathbf{n}\end{array}$} & \multicolumn{3}{|c|}{ Average Area } & \multicolumn{3}{|c|}{ \% RSD } \\
\hline & & $\begin{array}{l}\text { Paracetam } \\
\text { ol }\end{array}$ & $\begin{array}{l}\text { Phenylpropan } \\
\text { olamine }\end{array}$ & $\begin{array}{l}\text { Triprolidin } \\
\text { e }\end{array}$ & $\begin{array}{l}\text { Paraceta } \\
\text { mol }\end{array}$ & $\begin{array}{l}\text { Phenylpropano } \\
\text { lamine }\end{array}$ & $\begin{array}{l}\text { Triprolidin } \\
\text { e }\end{array}$ \\
\hline \multirow{2}{*}{$\begin{array}{l}\text { Flow } \\
\text { rate }\end{array}$} & $0.8 \mathrm{~min}$ & 9546.055 & 3510.605 & 1022.257 & 0.216 & 0.332776 & 0.711444 \\
\hline & $1.2 \mathrm{~min}$ & 8691.59 & 3188.266 & 932.7417 & 0.251 & 0.62451 & 0.265757 \\
\hline \multirow[t]{2}{*}{$\begin{array}{l}\text { Mobile } \\
\text { phase }\end{array}$} & $\begin{array}{l}\text { Water } \\
\text { (pH 4.0): } \\
\text { Methano } \\
1 \quad(72: 28 \\
\mathrm{v} / \mathrm{v})\end{array}$ & 8836.413 & 3247.385 & 947.9253 & 0.221 & 0.289671 & 0.541888 \\
\hline & $\begin{array}{l}\text { Water } \\
\text { (pH 4.0): } \\
\text { Methano } \\
1 \quad(68: 32 \\
\mathrm{v} / \mathrm{v})\end{array}$ & 9366.981 & 3445.988 & 1004.45 & 0.694 & 0.885241 & 0.795956 \\
\hline \multirow[t]{2}{*}{$\mathrm{pH}$} & 6.2 & 9056.592 & 3322.327 & 973.375 & 0.352 & 0.633679 & 0.299421 \\
\hline & 5.8 & 8877.534 & 3264.259 & 951.1223 & 0.462 & 0.423682 & 0.886248 \\
\hline
\end{tabular}




\section{Specificity}

The specificity of proposed method is justified by the chromatograms of blank, placebo, standard and sample solutions under same chromatographic conditions shown in figure 9. The placebos did not interfere in determination of Paracetamol, Phenylpropanolamine and Triprolidinein commercial tablet. Specificity of the developed method was also evaluated by applying different stress conditions (oxidation, acid, base, thermal and photolytic) to Paracetamol, Phenylpropanolamine and Triprolidine tablet.

(a)

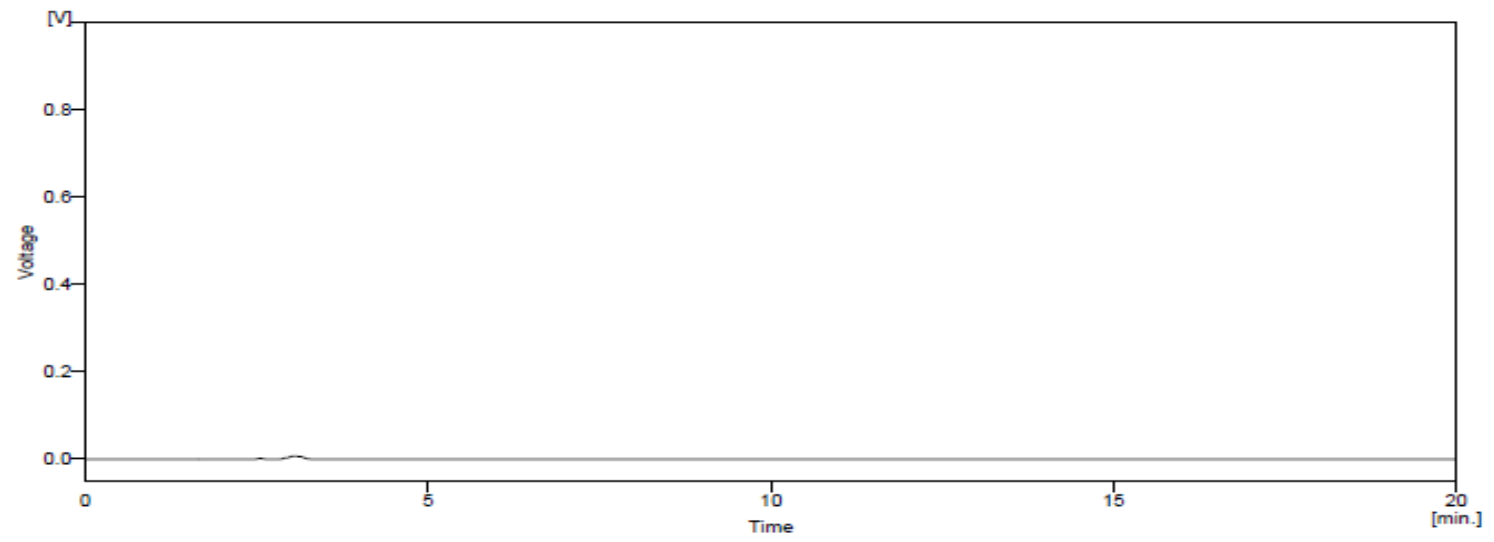

(b)

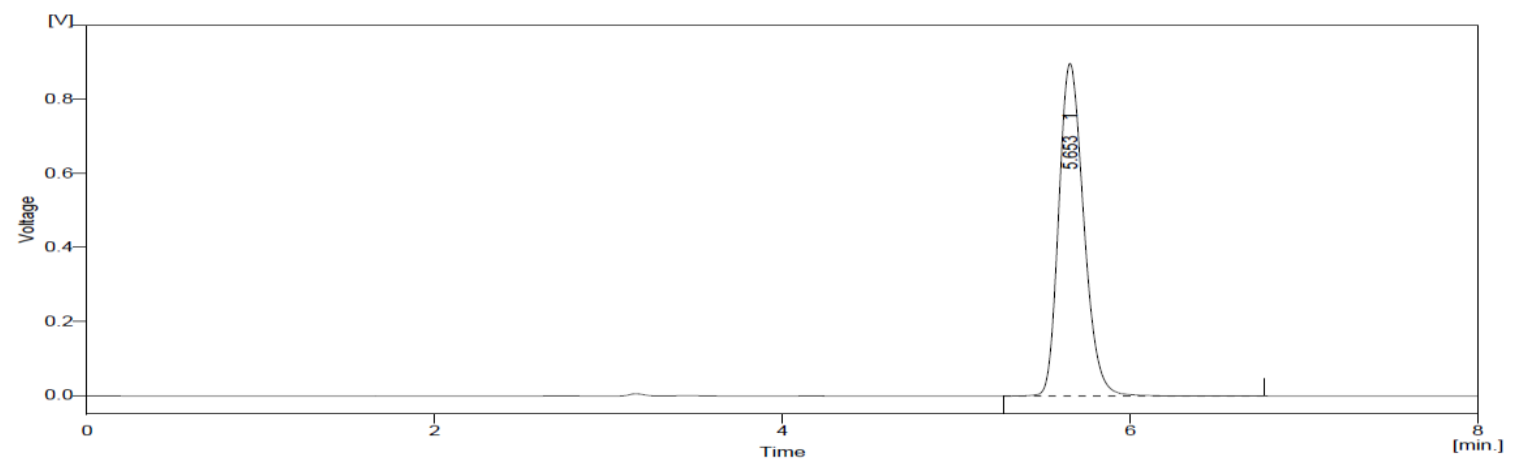

(c)

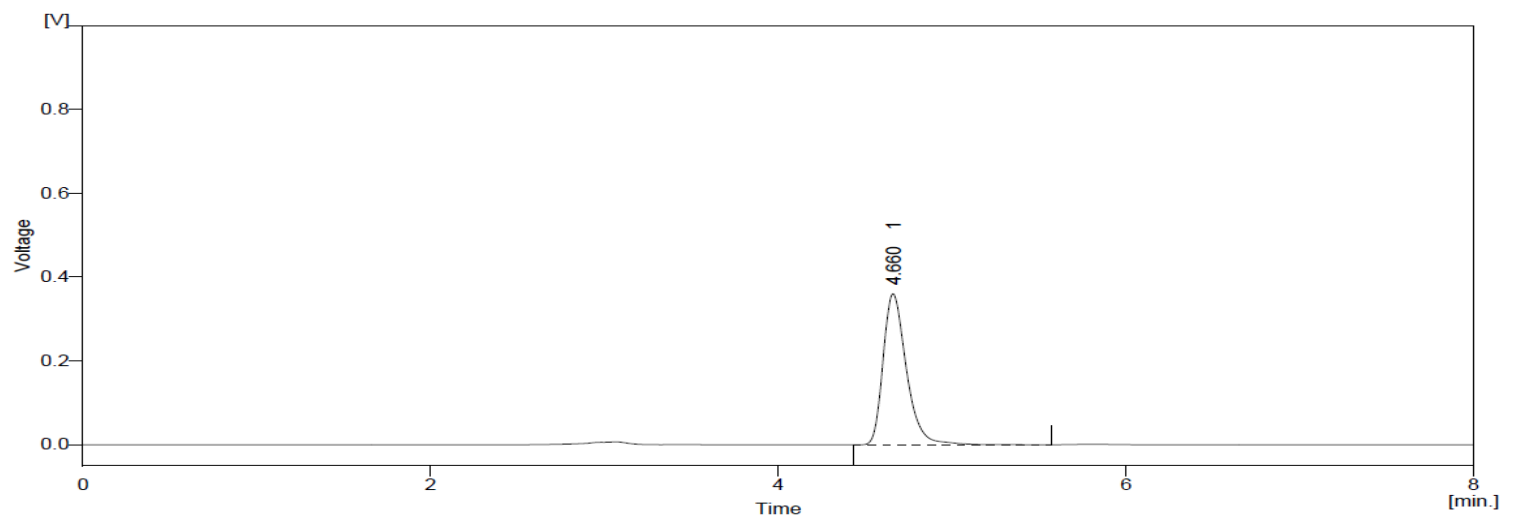


(d)

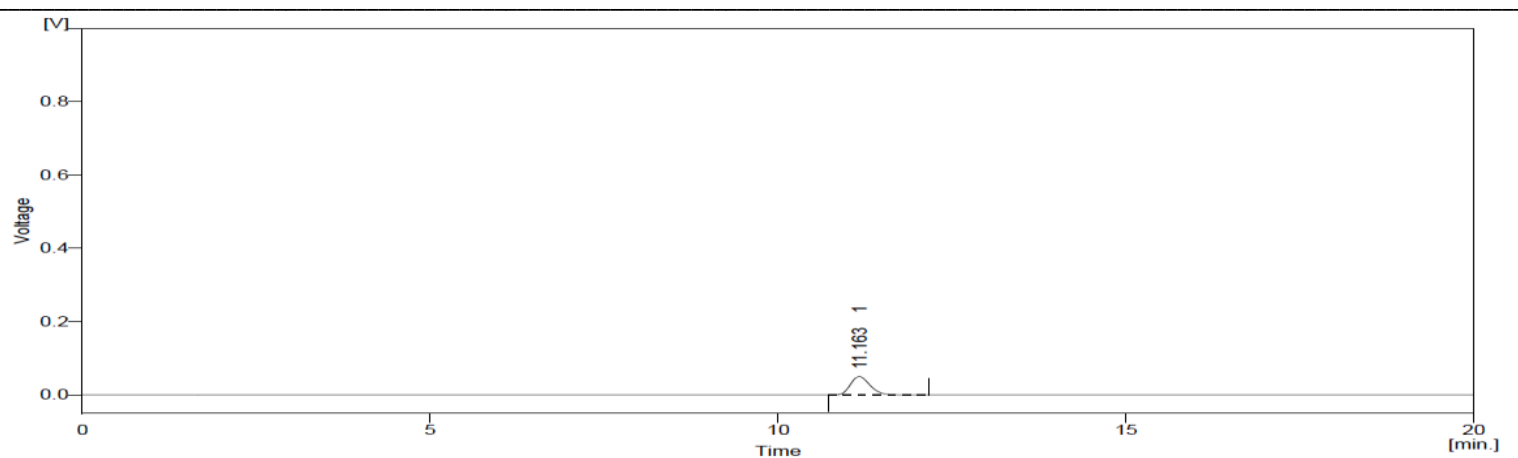

(e)

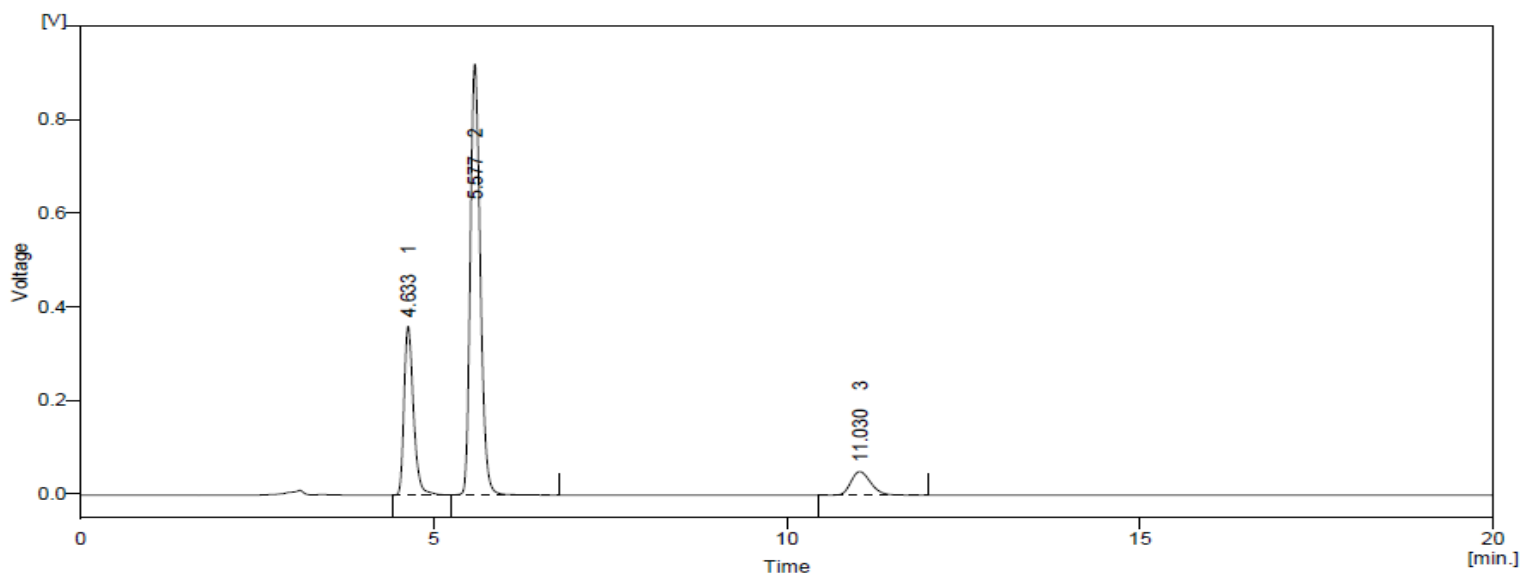

(f)

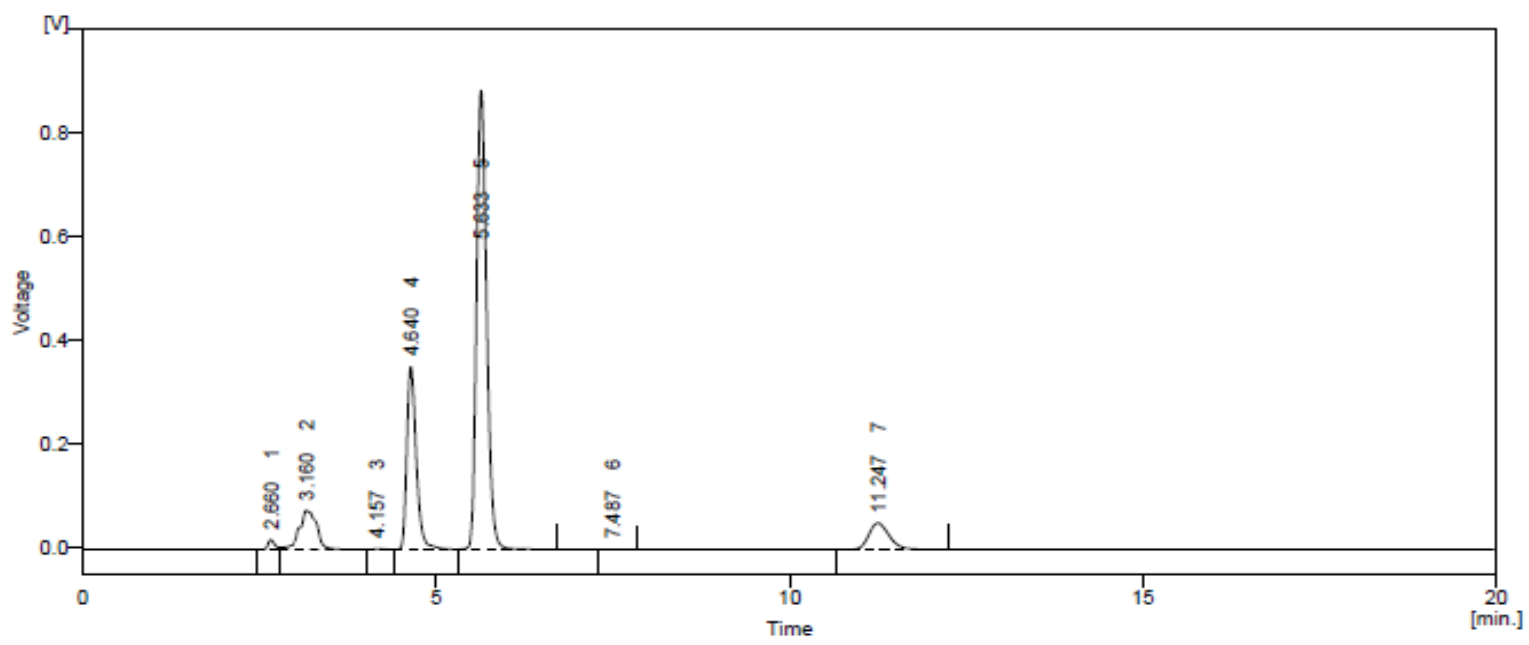

Fig 9: Chromatograms of (a) Blank, (b) Paracetamol, (c) Phenylpropanolamine,(d) Triprolidine, (e) Standard mixture and (f) Sample mixture

\section{Degradation Study}

From the results of forced degradation studies showed that these components do not remained intact under stressed conditions and hence special storage conditions should be provided for the dosage form. The specificity studies showed that the principle peaks were well resolved (peak purity 99.99\%) and free from any interference from the degradation product. The stress conditions were applied and degraded products of all three drugs are compared and showed in table 11 and 
chromatograms are in figure 10 . From the stress studies it is concluded that substantial degradation of Paracetamol, Phenylpropanolamine and Triprolidine occurred in acid, basic, oxidative thermal and photolytic stress conditions. The degradation products (impurities) in addition to percent degradation under acid, base, oxidation, thermal and photolytic stresses have unique retention times (RT) to acidic stress (9 impurities, RT: $4.670 \mathrm{~min}, 5.667 \mathrm{~min}, 7.527 \mathrm{~min}, 7.717$ $\mathrm{min}, 9.153 \mathrm{~min}$ and $9.633 \mathrm{~min}, 10.457 \mathrm{~min}, 11.147 \mathrm{~min}$ and $12.513 \mathrm{~min}$ ), basic stress (8 impurities, RT: 4.650 min, $5.667 \mathrm{~min}, 6.807 \mathrm{~min}$ and $7.900 \mathrm{~min}, 9.647 \mathrm{~min}$, $10.487 \mathrm{~min}, 11.160 \mathrm{~min}$ and $12.653 \mathrm{~min}$ ), oxidative stress (8impurities, RT: $3.810 \mathrm{~min}, 4.673 \mathrm{~min}, 5.627$ $\mathrm{min}, 7.840 \mathrm{~min}, 8.420 \mathrm{~min}, 9.623 \mathrm{~min}, 10.193 \mathrm{~min}$ and $11.217 \mathrm{~min}$ ), thermal stress (7 impurities, RT: 4.653 min, $5.643 \mathrm{~min}, 7.027 \mathrm{~min}, 8.367 \mathrm{~min} .9 .490 \mathrm{~min}$, $10.007 \mathrm{~min}$ and $11.183 \mathrm{~min})$ and photolytic stress (12 impurities, RT: $4.650 \mathrm{~min}, 5.670 \mathrm{~min}, 6.443 \mathrm{~min}, 6.873$ min, $7.703 \mathrm{~min}, 8.300 \mathrm{~min}, 8.750 \mathrm{~min}, 9.777 \mathrm{~min}$, $10.540 \mathrm{~min}, 11.197 \mathrm{~min}, 12.740$ minand $14.193 \mathrm{~min}$ ). Degradation studies justified the method specificity for its intended application.

Table 11: Stability study results

\begin{tabular}{|c|c|c|c|c|c|c|c|}
\hline \multirow{3}{*}{$\begin{array}{c}\text { Type of } \\
\text { degradation }\end{array}$} & \multirow[t]{3}{*}{ Drug } & \multirow{3}{*}{$\begin{array}{c}\text { Peak Area } \\
\text { of } \\
\text { Standard }\end{array}$} & \multirow{3}{*}{ Conditions } & \multicolumn{4}{|c|}{ Peak area } \\
\hline & & & & \multicolumn{2}{|c|}{ Standard } & \multicolumn{2}{|c|}{ Sample } \\
\hline & & & & Area & \% Deg. & Area & \% Deg. \\
\hline \multirow{3}{*}{$\begin{array}{l}\text { Acid } \\
\text { degradation }\end{array}$} & Paracetamol & 9085.492 & \multirow{3}{*}{$\begin{array}{l}4 \text { hours at } \\
\text { Room } \\
\text { Temperature }\end{array}$} & 7142.284 & 21.38803 & 7184.386 & 20.92463 \\
\hline & $\begin{array}{l}\text { Phenylpropanola } \\
\text { mine }\end{array}$ & 3346.163 & & 2778.715 & 16.96 & 2768.554 & 17.26 \\
\hline & Triprolidine & 974.959 & & 793.635 & 18.59812 & 801.740 & 17.767 \\
\hline \multirow{3}{*}{$\begin{array}{l}\text { Base } \\
\text { degradation }\end{array}$} & Paracetamol & 9085.492 & \multirow{3}{*}{$\begin{array}{l}4 \text { hours at } \\
\text { Room } \\
\text { Temperature }\end{array}$} & 6301.313 & 30.64423 & 6394.391 & 29.61976 \\
\hline & $\begin{array}{l}\text { Phenylpropanola } \\
\text { mine }\end{array}$ & 3346.163 & & 2653.422 & 20.70 & 2594.504 & 22.46 \\
\hline & Triprolidine & 974.959 & & 780.623 & 19.93274 & 779.570 & 20.041 \\
\hline \multirow{3}{*}{$\begin{array}{l}\text { Oxidative } \\
\text { degradation }\end{array}$} & Paracetamol & 9085.492 & \multirow{3}{*}{$\begin{array}{l}5 \text { hours at } \\
\text { Room } \\
\text { Temperature }\end{array}$} & 6136.852 & 32.45438 & 6288.912 & 30.78072 \\
\hline & $\begin{array}{l}\text { Phenylpropanola } \\
\text { mine }\end{array}$ & 3346.163 & & 2446.238 & 26.89 & 2478.91 & 25.92 \\
\hline & Triprolidine & 974.959 & & 745.265 & 23.55935 & 754.969 & 22.564 \\
\hline \multirow{3}{*}{$\begin{array}{l}\text { Thermal } \\
\text { degradation }\end{array}$} & Paracetamol & 9085.492 & \multirow{3}{*}{$\begin{array}{l}24 \text { hours at } \\
105^{\circ} \mathrm{C}\end{array}$} & 6331.444 & 30.31259 & 6372.831 & 29.85706 \\
\hline & $\begin{array}{l}\text { Phenylpropanola } \\
\text { mine }\end{array}$ & 3346.163 & & 2152.561 & 35.67 & 2192.828 & 34.47 \\
\hline & Triprolidine & 974.959 & & 623.33 & 36.06603 & 626.050 & 35.787 \\
\hline \multirow{3}{*}{$\begin{array}{l}\text { Photolytic } \\
\text { degradation }\end{array}$} & Paracetamol & 9085.492 & \multirow{3}{*}{$\begin{array}{l}24 \text { hours in } \\
\text { UV chamber }\end{array}$} & 7290.649 & 19.75504 & 7358.982 & 19.00293 \\
\hline & $\begin{array}{l}\text { Phenylpropanola } \\
\text { mine }\end{array}$ & 3346.163 & & 2818.476 & 15.77 & 2855.725 & 14.66 \\
\hline & Triprolidine & 974.959 & & 782.466 & 19.7437 & 775.488 & 20.459 \\
\hline
\end{tabular}

(a)

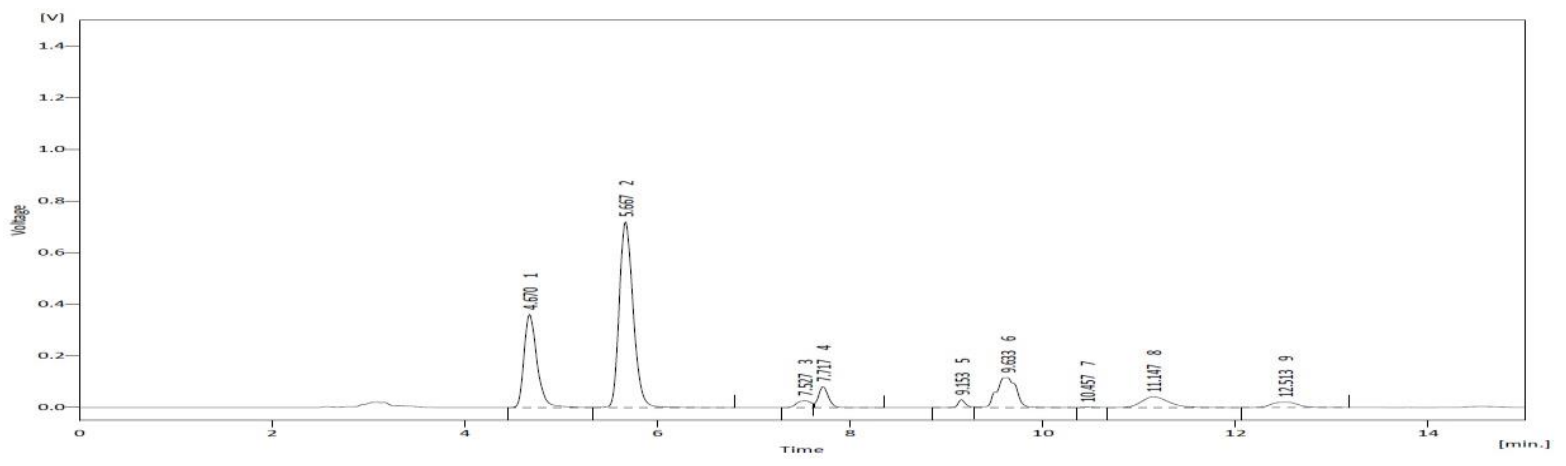




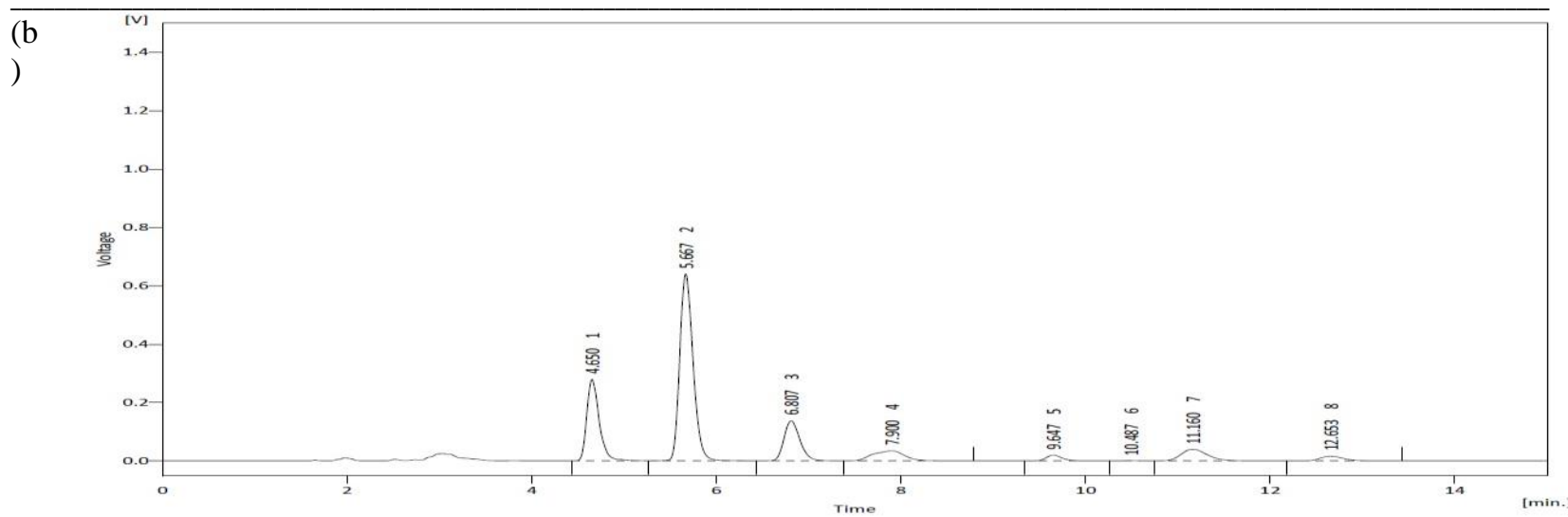

(c)

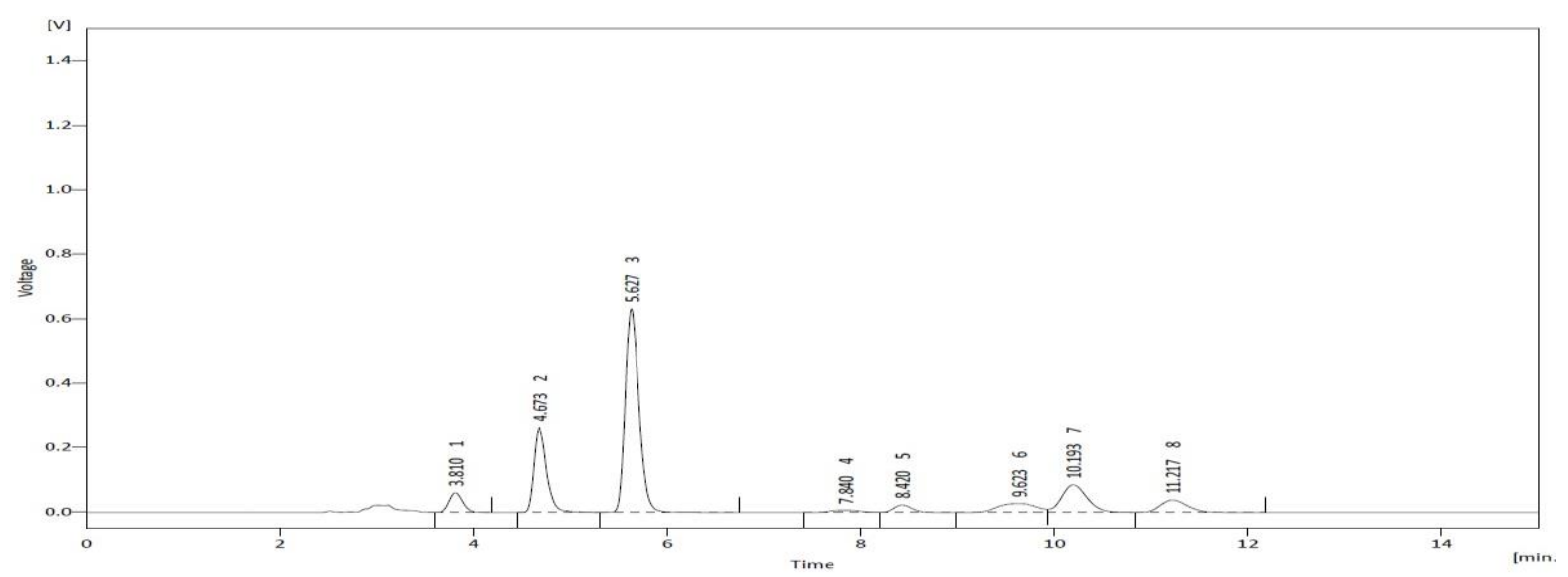

(d)

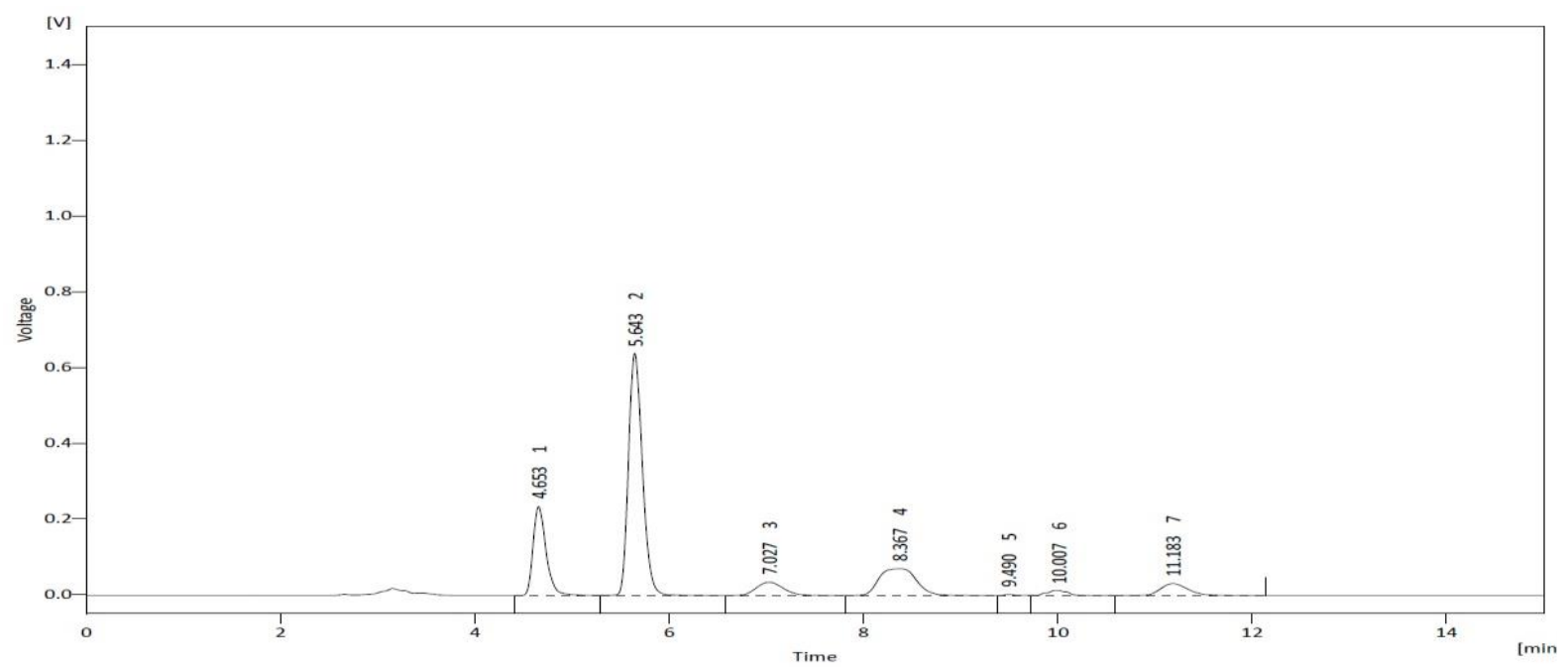




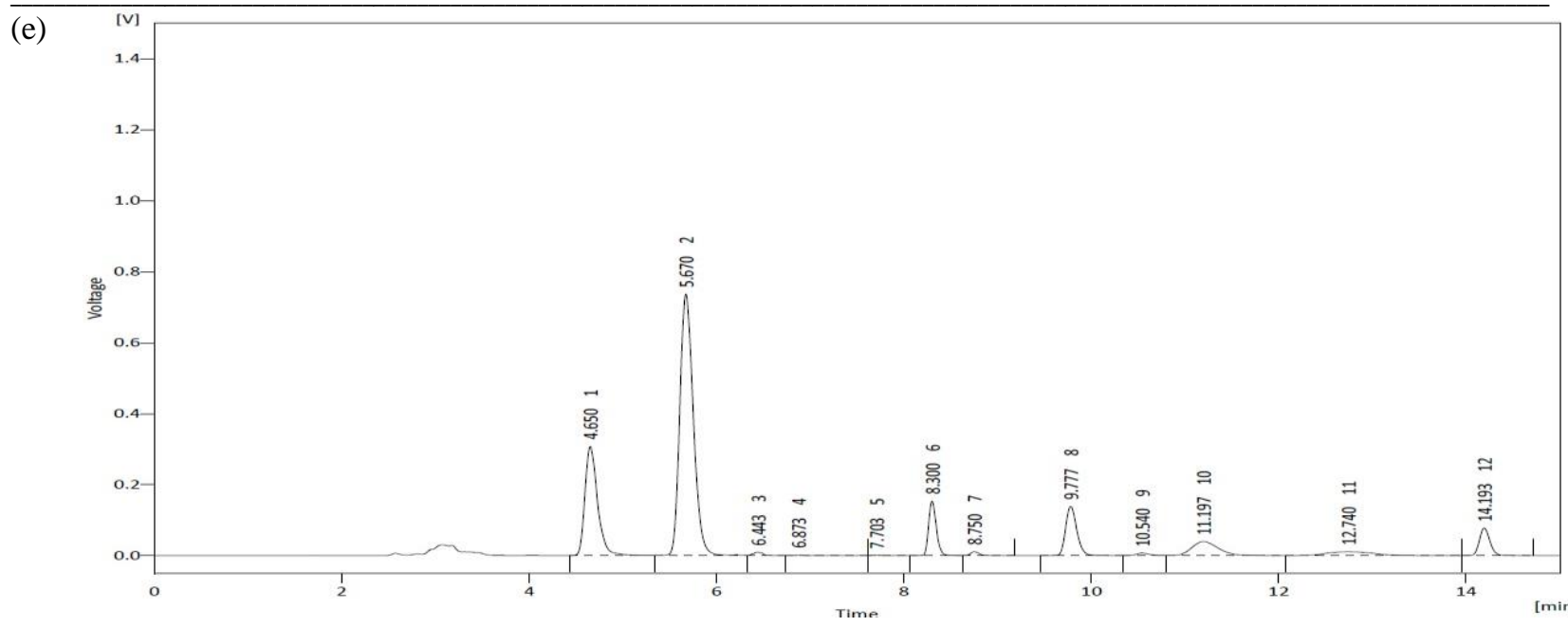

Fig 10: Chromatograms of (a) Acid Degradation, (b) Base Degradation (c) Oxidative Degradation, (d) Thermal Degradation, (e) Photolytic Degradation

\section{Results and Discussion}

To develop a new RP-HPLC method, several mobile phase compositions were tried. A satisfactory separation and good peak symmetry was obtained with BDS hypersil $\mathrm{C}_{18}, 250 \mathrm{~mm} \times 4.6 \mathrm{~mm}$ internal diameter, $5 \mu$ particle size or equivalent column and mobile phase comprising of Water ( $\mathrm{pH} 4.0)$ : Methanol (70:30v/v) at a flow rate of $1.0 \mathrm{ml} / \mathrm{min}$ to get better reproducibility and repeatability. Quantification was achieved with UV detection at $220 \mathrm{~nm}$ based on peak area. The retention time for Paracetamol, Phenylpropanolamine and Triprolidine were found to be $5.603 \mathrm{~min}, 4.653 \mathrm{~min}$ and $11.083 \mathrm{~min}$ respectively.

The optimized method was validated as per ICH guidelines. The system suitability parameters observed by using this optimized condition were reported. The method was found to be linear in the concentration range of $50-150 \mu \mathrm{g} / \mathrm{mL}$ with correlation coefficient of 0.9994 for Paracetamol, 2.5-7.5 $\mu \mathrm{g} / \mathrm{mL}$ with correlation coefficient of 0.9995 for Phenylpropanolamine, and 2.5-7.5 $\mu \mathrm{g} / \mathrm{mL}$ with correlation coefficient of 0.9992 for Triprolidine. The results of recovery study $(99.206 \%$ for Paracetamol,98.923\% for Phenylpropanolamine and $99.727 \%$ for Triprolidine) suggest that the method has good recovery. The precision of the proposed method was carried in terms of the repeatability. The low\% RSD (<2) values of $0.778 \%, 0.869 \%$ and $0.924 \%$ variation for Paracetamol, Phenylpropanolamine and Triprolidine, respectively, reveals that the proposed method is precise. The LOD and LOQ values for Paracetamol were found to be
$3.716 \mu \mathrm{g} / \mathrm{ml} \quad$ and $\quad 11.261 \mu \mathrm{g} / \mathrm{ml}$, for Phenylpropanolamine were $0.174 \mu \mathrm{g} / \mathrm{ml}$ and $0.529 \mu \mathrm{g} / \mathrm{ml}$ and for Triprolidine were $0.210 \mu \mathrm{g} / \mathrm{ml}$ and $0.638 \mu \mathrm{g} / \mathrm{ml}$. The results of robustness in the present method showed no significant changes. The results of analysis of drop indicated that no interference due to common excipients was observed with the developed method. Degradation studies justified the method specificity for its intended application. Therefore, the proposed method can be used for routine analysis of three drugs in their combined pharmaceutical dosage form.

\section{Conclusion}

A simple, precise, accurate and rapid method was developed for simultaneous estimation of Paracetamol, Phenylpropanolamine and Triprolidinefrom pure and its dosage forms. The mobile phase is simple to prepare and economical. The sample recoveries in the formulation were in good agreement with their respective label claims. Hence, this method can be easily and conveniently adopted for routine analysis of Paracetamol, Phenylpropanolamine and Triprolidinein pure form and its dosage form.

\section{Acknowledgments}

The authors are thankful to Management of Sanjeevan College of Pharmacy, Dausa, Rajasthan for providing needed facilities to carry out this research work. The authors are also thankful to Yash Pharma for providing gift samples of Paracetamol, Phenylpropanolamine and Triprolidine. 


\section{References}

1. Acheampong A, Gyasi WO, Darko G, Apau J, Addai-Arhin S. Validated RP-HPLC method for simultaneous determination and quantification of chlorpheniramine maleate, paracetamol and caffeine in tablet formulation. SpringerPlus. 2016;5:625.

2. Pappula N, Chintala P. Development and Validation of RP-HPLC Method for the Simultaneous Estimation of Paracetamol and Flupirtine Maleate in Pharmaceutical Dosage Form2014. 34-9 p.

3. Kumar $A^{1}$, Sharma R, Nair A, Saini G.. Development and validation of RP-HPLC method for simultaneous estimation of nimesulide, phenylephrine hydrochloride, chlorpheniramine maleate and caffeine anhydrous in pharmaceutical dosage form. Acta Pol Pharm. 2012;69(6):1017-22.

4. Yang H. How Many Batches Are Needed for Process Validation under the New FDA Guidance?
PDA journal of pharmaceutical science and technology. 2013;67(1):53-62.

5. Jahan MS, Islam MJ, Begum R, Kayesh R, Rahman A. A Study of Method Development, Validation, and Forced Degradation for Simultaneous Quantification of Paracetamol and Ibuprofen in Pharmaceutical Dosage Form by RPHPLC Method. Analytical Chemistry Insights. 2014;9:75-81.

6. Lacaze C, Kauss $\mathrm{T}$, Kiechel J-R, Caminiti A, Fawaz F, Terrassin L, et al. The initial pharmaceutical development of an artesunate/amodiaquine oral formulation for the treatment of malaria: a public-private partnership. Malaria Journal. 2011;10:142.

7. Naveen P, Lingaraju HB, Deepak M, Medhini B, Prasad KS. Method Development and Validation for the Determination of Caffeine: An Alkaloid from Coffea arabica by High-performance Liquid Chromatography Method. Pharmacognosy Research. 2018;10(1):88-91.

Conflict of Interest: None Source of Support: Nil 